\title{
Polystyrene and Polyethylene Microplastics Decrease Cell Viability and Dysregulate Inflammatory and Oxidative Stress Markers of MDCK and L929 Cells In Vitro
}

\author{
Swetha Palaniappan ${ }^{1} \cdot$ Chakravarthy Marx Sadacharan ${ }^{2}\left[\right.$ B $\cdot$ Bahman Rostama ${ }^{3,4}(\mathbb{C}$
}

Received: 25 March 2021 / Revised: 1 July 2021 / Accepted: 20 July 2021 / Published online: 25 July 2021

(c) The Author(s), under exclusive licence to Springer Nature B.V. 2021

\begin{abstract}
Microplastics are ubiquitous environmental pollutants that are a growing concern to many ecosystems, as well as human health. Many of the effects of microplastics on mammalian cells and tissues remain unknown. To address this, we treated L929 murine fibroblasts and Madin-Darby canine kidney (MDCK) epithelial cell lines with $1 \mu \mathrm{g} / \mathrm{mL}, 10 \mu \mathrm{g} / \mathrm{mL}$, or $20 \mu \mathrm{g} /$ $\mathrm{mL}$ of polyethylene (PE) or polystyrene (PS) microspheres in vitro for 6 and $24 \mathrm{~h}$ and measured the resulting changes in cell viability, metabolism, and transcriptional expression of inflammatory cytokines and antioxidant enzymes. We observed dosedependent decreases in cell viability corresponding to increases in doses of both PE and PS. We conducted cell metabolism assays and observed dose-dependent increases in metabolism per cell with increasing doses of both PE and PS. Similarly, we also observed increased expression of the superoxide dismutase-3 gene (SOD3), indicating oxidative stress caused by the microplastics treatments. We also observed increased expression of $T N F \alpha$, but decreased expression of IFN $\beta$, suggesting different mechanisms by which the microplastics regulate inflammatory responses in mammalian cells. Our results contribute new data to the growing understanding of the effects of microplastics on mammalian cells and indicate complex cellular stress responses to microplastics in the environment.
\end{abstract}

Keywords Microplastics $\cdot$ Cell viability $\cdot$ Oxidative stress $\cdot$ Cellular metabolism $\cdot$ Inflammatory cytokines

\section{Introduction}

Microplastics are increasingly recognized as ubiquitous pollutants in the environment, with the same properties that make them durable and desirable synthetic organic polymers also conferring on them the ability to persist and spread. Microplastics $5 \mathrm{~mm}$ and smaller decompose slowly, with ultraviolet radiation, hydrolysis, and physical degradation converting them to fragments smaller than $0.0001 \mathrm{~mm}$,

Bahman Rostama

bahman.rostama@maine.edu

1 Cape Elizabeth High School, Cape Elizabeth, ME, USA

2 School of Biological Sciences, College of Arts \& Sciences, University of New England, Biddeford, ME 04005, USA

3 Department of Biomedical Sciences, College of Osteopathic Medicine, University of New England, Biddeford, ME 04005, USA

411 Hills Beach Road, Stella Maris \#408, Biddeford, ME 04005-9526, USA known as nanoplastics, as defined by the European Commission (Alexy et al. 2020).

Microplastics have been found to be able to enter tissues of living organisms, including humans, via ingestion, inhalation, and topical absorption (Deng et al. 2017; Huffer et al. 2018; Pivokonsky et al. 2018; Prata et al. 2020; Zarus et al. 2021; Zhang et al. 2020b). Although the full spectrum of their effects and mechanisms is yet to be determined, microplastic bioaccumulation in multiple biota through higher trophic levels has the potential to amplify their effects by their increasing dosage in top predators (such as humans) and can affect functions as varied as feeding behaviors, metabolism, and fecundity (da Costa Araujo and Malafaia 2021; Foley et al. 2018). Sampling different environments and geographic locations has shown microplastic burdens of varying abundance, types, sizes, shapes, and ages, contributing to a variety of health dangers including bacterial antibiotic resistance (Su et al. 2021; Wang et al. 2020).

As synthetic human-made polymers, microplastic contamination of the environment has numerous diverse sources of origin, including car tires, effluents from clothes washers 
and dryers, and the slow degradation of littered cigarette butts (Belzagui et al. 2021; Karkkainen and Sillanpaa 2020; Koski et al. 2021; Mengistu et al. 2021). Microplastics are not always byproducts, as they can be incorporated specifically for their properties into products such as coatings, cosmetics, cleaning agents, and medical applications (Zarus et al. 2021). Thus, humans have many routes of microplastics exposure such as food (Al-Sid-Cheikh et al. 2018; Razeghi et al. 2021; Ribeiro et al. 2020; Zarus et al. 2021), food packaging (Zarus et al. 2021), medical implants (Hicks et al. 1996; Urban et al. 2000), and baby bottles (Li et al. 2020a), and multiple studies have found microplastics in human stool samples (Schwabl et al. 2019; Zhang et al. 2020a). Estimates put human ingestion of microplastics at 40,000-50,000 particles per person per year (Cox et al. 2019), increasing to 70,000-120,000 particles when including inhalation (Cox et al. 2020; Prata 2018), with possible further exacerbation due to recent increased synthetic mask-wearing due to the COVID-19 pandemic (Li et al. 2020c).

Studies have found that after ingestion microplastics can undergo persorption from the gut to the lymphatics and onto other tissues (Hussain et al. 2001; Volkheimer 1975). Similar translocations of nanoplastics have been found to originate from the lungs via inhalation (Choi et al. 2010). Animal models have found microplastic accumulation in mammalian male (Jin et al. 2021) and female (An et al. 2021; Hou et al. 2021) gonadal tissues, possibly affecting fertility and reproductive capacity. Inside the body, in addition to their physical and mechanical interactions, microplastics can also leach chemical into tissues and circulation, including chemicals applied during manufacturing (e.g., bisphenols, phthalates, perfluoridated compounds, brominated flame retardants, UV stabilizers) (Cox et al. 2019) and for aged plastics, substances absorbed and accumulated from the environment (e.g., organic pesticides, polyaromatic hydrocarbons, heavy metals, and pathogens) (Alimba and Faggio 2019; Cox et al. 2019; Scopetani et al. 2018; Torres et al. 2021).

Until recently, due to frequent pollution of lakes, rivers, and oceans, research articles often focused on wild or model aquatic organisms such as mussels, urchins, and fish to analyze the effects of microplastics (Akhbarizadeh et al. 2018; Browne et al. 2008; Nobre et al. 2015). With increased awareness of the prevalence of microplastics in many of the environments with which humans are in direct and intimate contact, research has shifted from analysis of fish and invertebrates to mammalian animal models and cell lines. Among these, in vivo studies have revealed disruptions of gut homeostasis (Choi et al. 2021b; Liang et al. 2021), increased reactive oxygen species generation and inflammation (Ijaz et al. 2021), genotoxicity and lipotoxicity (Deng et al. 2017; Gonzalez-Acedo et al. 2021), and exacerbated bone resorption (Markel et al. 2009). In vitro experiments (often using human or rodent cell lines) have similarly demonstrated the adverse effects of microplastics, including immune cell activation (Pearl et al. 2011), inflammatory cytokine release (Schirinzi et al. 2017), bone resorption activity (Zhang et al. 2008), decreased survival (Van Tienhoven et al. 2006), cytostructural perturbations and neurotoxicity (Gonzalez-Acedo et al. 2021), and loss of phenotypic cellular behaviors (Lee et al. 2021).

Despite the existing knowledge about microplastics on body burdens and potential impacts on physiology, there are, as of yet, many more molecular mechanisms to be elucidated by which they can impact mammalian health at the cellular level. Furthermore, specific microplastic types, sizes, and shapes can impact various organisms and tissue types differently (Blackburn and Green 2021). Therefore, the goal of this study was to measure the impacts of pristine, virgin microspheres of polystyrene (PS) and polyethylene (PE) on the viability, metabolism, and the transcriptional expression changes in inflammatory and oxidative stress genes of the cell lines MDCK (Madin-Darby canine kidney epithelial cells) and L929 (murine fibroblast cells). The two cell lines were chosen to represent two different mammalian organisms as well as two tissue types (epithelial lining cells and mesenchymal connective tissue cells). The viability, metabolism, and inflammatory and oxidative stress gene expression endpoint assays were selected, as they were oft-observed as targets of dysregulation in previous research studies. Two timepoints were chosen to represent the impacts of the microplastics on the cells, a short-term treatment of $6 \mathrm{~h}$ and a longer-term treatment of $24 \mathrm{~h}$. Based on the literature, we hypothesized that there would be differences between the effects of PS and PE on the two cell types on their metabolic activity and inflammatory cytokine gene expression, but that they would be similarly affected in their viability with increased cytotoxicity corresponding to microplastic dosage.

\section{Results}

\section{Microplastics Decreased Cell Viability in a Dose-Dependent Manner}

Relative to vehicle controls, the majority of microplastic treatment conditions, in both the $6 \mathrm{~h}$ and $24 \mathrm{~h}$ modalities, reduced viability in both cell lines, as measured via hemacytometer (Fig. 1). The two exceptions were both observed in the lowest concentration conditions, at $1 \mu \mathrm{g} / \mathrm{mL}$ PE at $6 \mathrm{~h}$ on the MDCK cells (although this was not statistically significant compared to vehicle control), and at $1 \mu \mathrm{g} / \mathrm{mL}$ PS at $24 \mathrm{~h}$ on the L929 cells, which was statistically significant (Fig. 1a and d). In almost all of the microplastic treatment conditions, the trend followed a dose-dependent decrease in cell viability, with the highest doses showing the greatest decreases in absolute cell numbers per well. The difference 

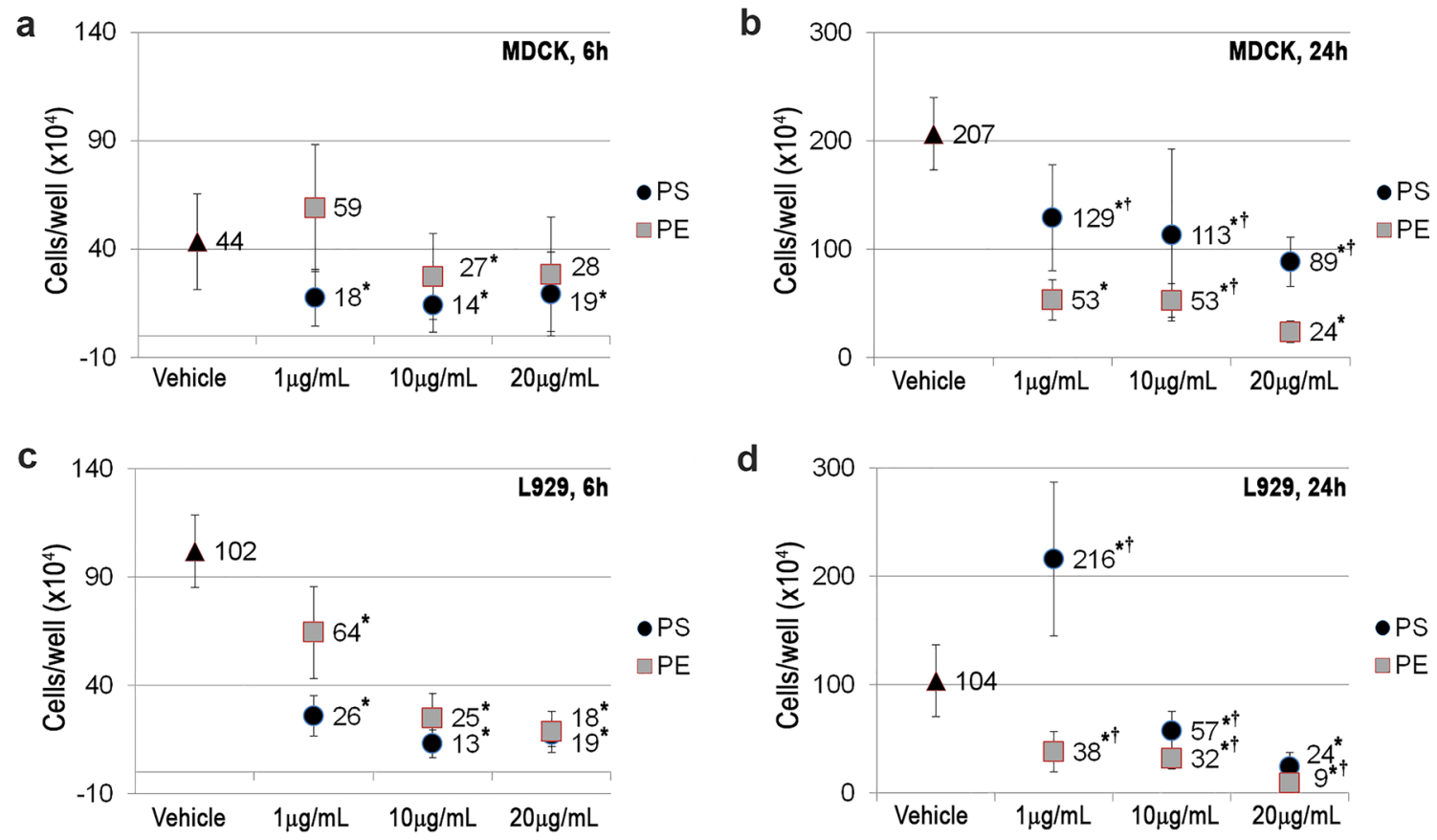

d

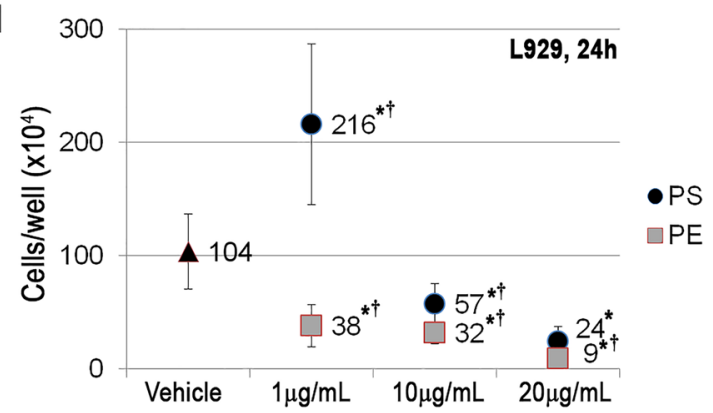

Fig. 1 PS and PE microplastics decreased the viability of MDCK and L929 cells in a dose-dependent manner. MDCK (a, b) and L929 (c, d) cells were treated with PS (filled circle) or PE (gray square) microplastics, or vehicle control (filled triangle) for $6 \mathrm{~h} \mathrm{(a,} \mathrm{c)} \mathrm{or} 24 \mathrm{~h} \mathrm{(b,d)}$ at $1 \mu \mathrm{g} / \mathrm{mL}, 10 \mu \mathrm{g} / \mathrm{mL}$, or $20 \mu \mathrm{g} / \mathrm{mL}$, and their viability was measured by total cell count per well. Each experiment was conducted in bio-

in total cells per well between 6 and $24 \mathrm{~h}$ for each condition indicates that there was continued proliferation despite the short-term impacts of the microplastics on viability, but that the effects also extended the dose-dependent trend of suppressing viability to suppressing proliferation as well.

\section{Microplastics Increased Cell Metabolic Rates in a Dose-Dependent Manner}

Cell metabolic rates were measured via MTT assay, whose reduction to an insoluble colorimetric precipitate is carried out by mitochondrial and cytoplasmic oxidoreductive enzymes that utilize rate-limiting $\mathrm{NADH}$ and $\mathrm{NAD}(\mathrm{P}) \mathrm{H}$ substrates, corresponding to metabolic rate. When normalized to total cells per well, the results of the MTT assay showed mostly dose-dependent increases with microplastics treatments. For both PS and PE, and at $6 \mathrm{~h}$ and $24 \mathrm{~h}$, the general trend was increasing metabolic rates as microplastics concentrations were increased, relative to vehicle controls. One of the exceptions to this was observed in the $6 \mathrm{~h}$ treatments at $20 \mu \mathrm{g} / \mathrm{mL}$ for both MDCK and L929, which was still much higher than vehicle control conditions, but decreased slightly relative to the $10 \mu \mathrm{g} / \mathrm{mL}$ dose. Two of the experimental conditions (PE at $6 \mathrm{~h}$ on the MDCK cells and PS at $24 \mathrm{~h}$ on the L929 cells) showed initial decreases in metabolic activity at

$1 \mu \mathrm{g} / \mathrm{mL}$ relative to vehicle controls, but were still part of the dose-dependent increases in metabolic rate within their groups. Interestingly, the highest impact on the increase in cell metabolic activity was observed with PE treatment at $20 \mu \mathrm{g} / \mathrm{mL}$ at $24 \mathrm{~h}$ for both MDCK and L929 cells, with 8.3fold and 10.8-fold increases, respectively, relative to vehicle control.

\section{Microplastics Decreased IL1 $\beta$ and Increased TNFa Inflammatory Cytokine Transcripts}

The transcriptional expression of two cytokines, $I L I \beta$ and $T N F \alpha$, were measured by qPCR to determine the potential inflammatory effects of microplastics on the two cell lines. As seen with cell viability and metabolism, the expression of the cytokines followed a dose-responsive trend, either directly or inversely correlating with the microplastics doses. However, the dose-dependent trends for the inflammatory cytokine expression changed in a differential manner, varying with cell type, the microplastic type, and occasionally with the $6 \mathrm{~h}$ versus $24 \mathrm{~h}$ treatment modalities.

Some of the dose-dependent trends that showed increases in cytokine expression, such as with $I L 1 \beta$ in PS treatment of L929 cells, PE treatment of MDCK cells, and PE treatment of L929 cells at $6 \mathrm{~h}$, had their highest magnitude fold 
changes at the $1 \mu \mathrm{g} / \mathrm{mL}$ dose, suppressed below that of vehicle control. In these conditions, the dose-dependent increase actually brought the $I L 1 \beta$ expression close to baseline by the $20 \mu \mathrm{g} / \mathrm{mL}$ dose. Similarly, the dose-dependent decrease of $T N F \alpha$ expression with the PS treatment of MDCK cells at $6 \mathrm{~h}$ started with the highest positive magnitude fold change at $1 \mu \mathrm{g} / \mathrm{mL}$, and the decreasing trendline by $20 \mu \mathrm{g} / \mathrm{mL}$ brought its expression down to baseline.

In the MDCK cells, it was interesting to note that at both $6 \mathrm{~h}$ and $24 \mathrm{~h}$ PS treatment induced a dose-dependent decrease in both $I L I \beta$ and $T N F \alpha$, and PE treatment induced a dose-dependent increase in both $I L 1 \beta$ and $T N F \alpha$.

Two generalized observations could also be made about the expression patterns of both $I L 1 \beta$ and TNF $\alpha$. Although each cytokine displayed dose-dependent changes in expression, $I L 1 \beta$ expression was almost always below the baseline, indicating that both microplastics suppressed its expression, as compared with vehicle control. Alternatively, the majority of the experimental conditions showed that $T N F \alpha$ was increased relative to vehicle control, with the exception of $20 \mu \mathrm{g} / \mathrm{mL}$ PS treatment of MDCKs, and 10 and $20 \mu \mathrm{g} / \mathrm{mL}$ PS treatments of L929s, which were below baseline.

\section{Microplastics Increased SOD3 Antioxidant Enzyme Transcripts}

To evaluate whether the microplastics potentially exerted any oxidative stress on the MDCK and L929 cells, the transcriptional expression of the antioxidant enzyme SOD3 was measured by qPCR. In most of the experimental conditions, microplastics-induced SOD3 expression was increased relative to vehicle control cells, albeit its expression exhibited dose-dependent trends similar to those of the inflammatory cytokines. SOD3 expression was significantly decreased relative to controls in the MDCK cells by PS treatment at $6 \mathrm{~h}$, at $1 \mu \mathrm{g} / \mathrm{mL}$ and $10 \mu \mathrm{g} / \mathrm{mL}$, and by PE at $6 \mathrm{~h}$, at $1 \mu \mathrm{g} /$ $\mathrm{mL}$. One of the patterns observed in the dose-response differences between the two cell lines was their $6 \mathrm{~h}$ response to both PS and PE, with the MDCK cells' expression trendline showing increased SOD3 transcripts directly corresponding to dosage, and the L929 cells showing decreasing SOD3 expression, inversely correlated to dosage. It was also interesting to note that the highest magnitude response in SOD3 expression, 7.8-fold induction, occurred at $6 \mathrm{~h}$ and at the lowest concentration $(1 \mu \mathrm{g} / \mathrm{mL})$ with PE treatment on the L929 cells.

\section{Discussion}

In this study, we report that microplastics treatments of two mammalian cell lines yielded dose-dependent decreases in cell viability, increases in cell metabolism and expression of the superoxide dismutase- 3 gene, and differential expression of inflammatory cytokine genes, with increased TNF $\alpha$ and decreased IL1 $\beta$.

Microplastics can impact cells and organisms directly and indirectly, physically and chemically, and via an array of harmful effects, including irritation, oxidative damage, impairment of digestion, genotoxicity, metabolic changes, chemical leaching, and fluctuations of the microbiome (Deng et al. 2017; Ibrahim et al. 2021; Jin et al. 2019; Kumar et al. 2020). As microplastics age and weather in the environment, their properties such as size, shape, surface charges, and surface-bound groups can change, significantly altering the mechanisms with which they interact with cells and tissues, including the ability to be endocytosed (Brachner et al. 2020; Mahadevan and Valiyaveettil 2021; Ramsperger et al. 2020; Zarus et al. 2021). For this study we used virgin, pristine microspheres of PS and PE to decrease the size range and to avoid the variables of different shapes, surface charges and groups, as well as foreign chemicals absorbed from the environment. Although both the PE and the PS were supplied as microspheres of the pure polymers, presumably without plasticizers or copolymers, the leaching of trace amounts of monomers or catalysts used in the manufacture each plastic type cannot be ruled out. The size of the microspheres used in this study was also $1 \mu \mathrm{m}$ or greater, decreasing the possibility of their endocytosis (Mahadevan and Valiyaveettil 2021), although the measurement of this property was beyond the scope of this study. Thus, the most likely mechanisms by which the microplastics impacted the cells used in this study were physical interactions with the cells and their adjacent in vitro environments.

In the current study, our analysis demonstrated a significant, positively correlated dose-dependent decrease in cell viability at both the $6 \mathrm{~h}$ and $24 \mathrm{~h}$ timepoints of the assay (Fig. 1). Previous research has shown the toxic effects of microplastics on cells and tissues, with effects such as DNA damage and mitochondrial dysfunction, and these underlying mechanisms, as well as activation of apoptotic pathways, may have contributed to the decreased cell viability observed here (Della Torre et al. 2014; Estrela et al. 2020; Li et al. 2020d; Wei et al. 2021).

The increased metabolic flux measured by our MTT assays (Fig. 2) indicate increased activation of the redox enzymes that utilize NADH and $\mathrm{NAD}(\mathrm{P}) \mathrm{H}$ substrates, albeit the localization of these enzymes within the cytoplasmic or mitochondrial compartments were beyond the scope of this study. However, if the cellular stress responses upregulated the mitochondrial CYP and cytochrome oxidase enzymatic activities, it could explain the corresponding increases in MTT processing per cell observed here (Ding et al. 2020; Wen et al. 2018). The induction of the superoxide dismutase-3 gene (Fig. 4) corroborates this possibility. Alternatively, as observed in some physiologic studies of 
a

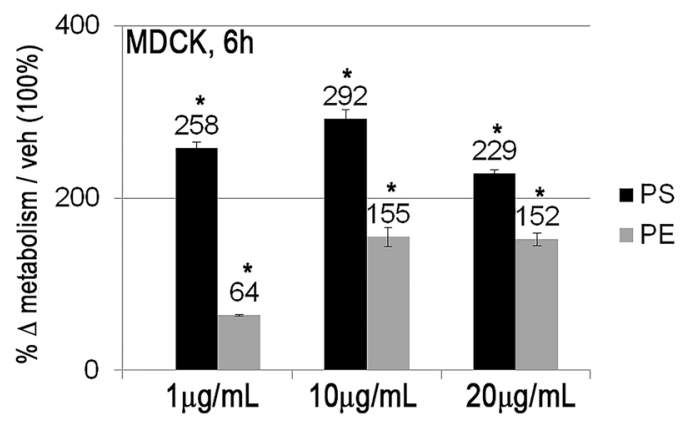

C

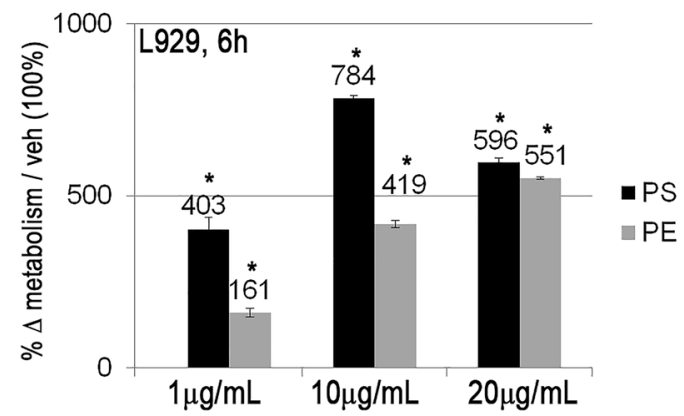

Fig. 2 PS and PE microplastics increased the metabolic enzyme activity of MDCK and L929 cells in a dose-dependent manner. $\operatorname{MDCK}(\mathbf{a}, \mathbf{b})$ and L929 (c, d) cells were treated with PS (black bars) or PE (gray bars) microplastics, or vehicle control for $6 \mathrm{~h}(\mathbf{a}, \mathbf{c})$ or $24 \mathrm{~h}(\mathbf{b}, \mathbf{d})$ at $1 \mu \mathrm{g} / \mathrm{mL}, 10 \mu \mathrm{g} / \mathrm{mL}$, or $20 \mu \mathrm{g} / \mathrm{mL}$, and the activity of their NADH- or NAD(P)H-dependent metabolic enzymes was measured by MTT assay. MTT measurements were normalized to cells per

microplastics, metabolic dysfunction can shift the availability of ATP or cause a switch in cell fuel sources, causing the cells to react by increasing energetic pathways to compensate (Deng et al. 2017; Jin et al. 2019; Lu et al. 2018).

Although the changes in expression of inflammatory cytokine genes followed dose-dependent trends (Fig. 3), the increase in $T N F \alpha$ concomitant with a decrease in $I L 1 \beta$ may be indicative of the mechanistic differences in how the cells react to the presence of the microplastics in their environment. Although the expression of both $T N F \alpha$ and $I L I \beta$ can both be co-regulated by the NF- $\kappa$ B pathway downstream of toll-like receptors (TLRs) and the recognition of damage-associated or pathogen-associated molecular patterns (DAMPs and PAMPs, respectively) (Oeckinghaus and Ghosh 2009), the upregulation of one inflammatory gene and downregulation of the other may be due to changes in expression of co-transcription factors such as HIF1 $\alpha$ or AP-1 (Roy et al. 2016; Walmsley et al. 2014; Wen and Ting 2013), or microRNAs (Li et al. 2020b; Shen et al. 2020; Zhao et al. 2020). However, previous studies have found diverse microplastic-induced inflammatory gene modulations, lending further credence to our findings (Choi et al. 2021a; Wu et al. 2020). b

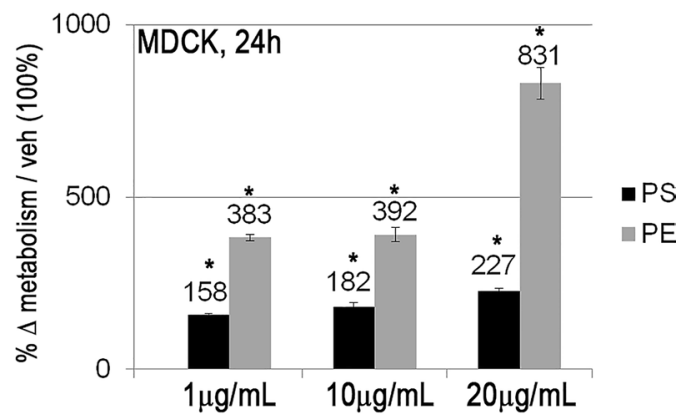

d

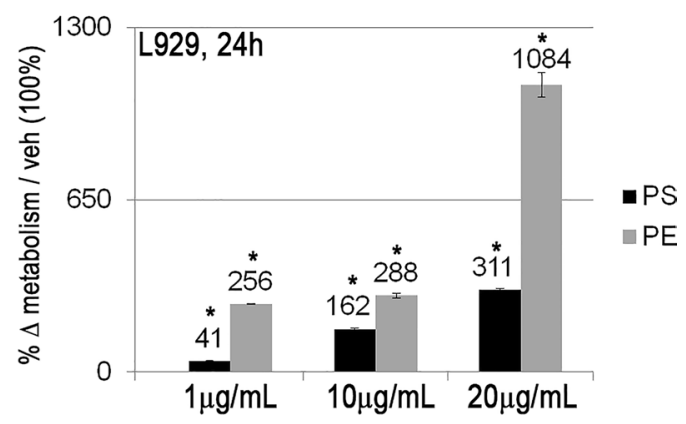

well, and \% change was calculated by comparing to the average of vehicle control wells (vehicle control values $=100 \%$ ). Each experiment was conducted in biological and technical duplicates. Error bars represent standard deviations. ${ }^{*}$ Statistical significance of $P$ values $<0.05$, as determined by student's $t$ test for each condition relative to vehicle control

Our study also found that the microplastics overall increased the gene expression of the secreted form of superoxide dismutase (SOD3), an indication that the cells were responding to extracellular oxidative stress at both timepoints (Fig. 4), albeit it was beyond the capabilities of our study to confirm the increased secretion or activity of SOD3 enzyme in the extracellular milieu. This finding is also supported by previous studies that found oxidative stress induced by microplastic-mediated interference in mitochondrial function, suppression of cellular antioxidant systems, and increased generation of reactive oxygen species (Abidli et al. 2021; An et al. 2021; Chen et al. 2021; Cortés et al. 2020; Liu et al. 2020; Wei et al. 2021).

In conclusion, our study provides new data regarding the effects of PE and PS on mammalian cells. With the plethora of effects that can arise from the myriad of variables and interactions between plastics, the environment, and target organisms and tissues, much work remains to be done to gain a broader understanding of the mechanisms of toxicity of microplastics. More thorough studies that include other plastic types and cells representing other mammalian tissues will be needed to shed further light on microplastic toxicity. 
IL $1 \beta \quad$ MDCK, PS
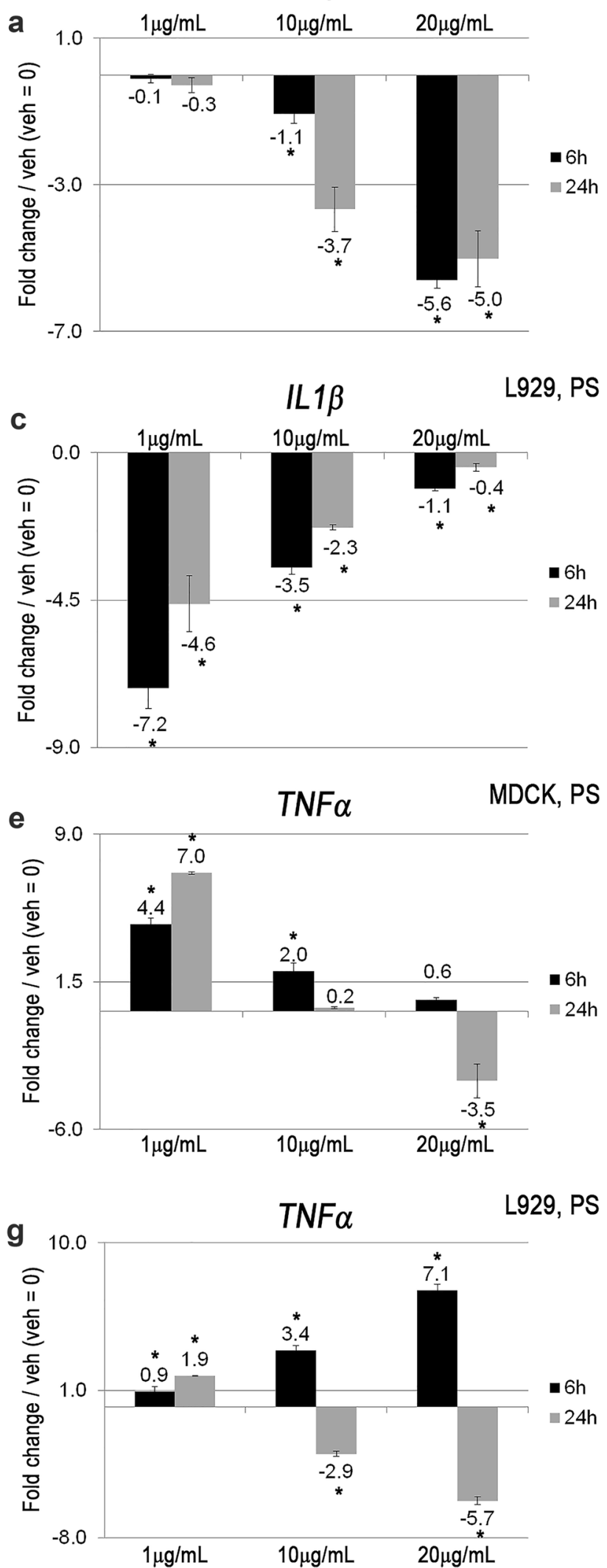
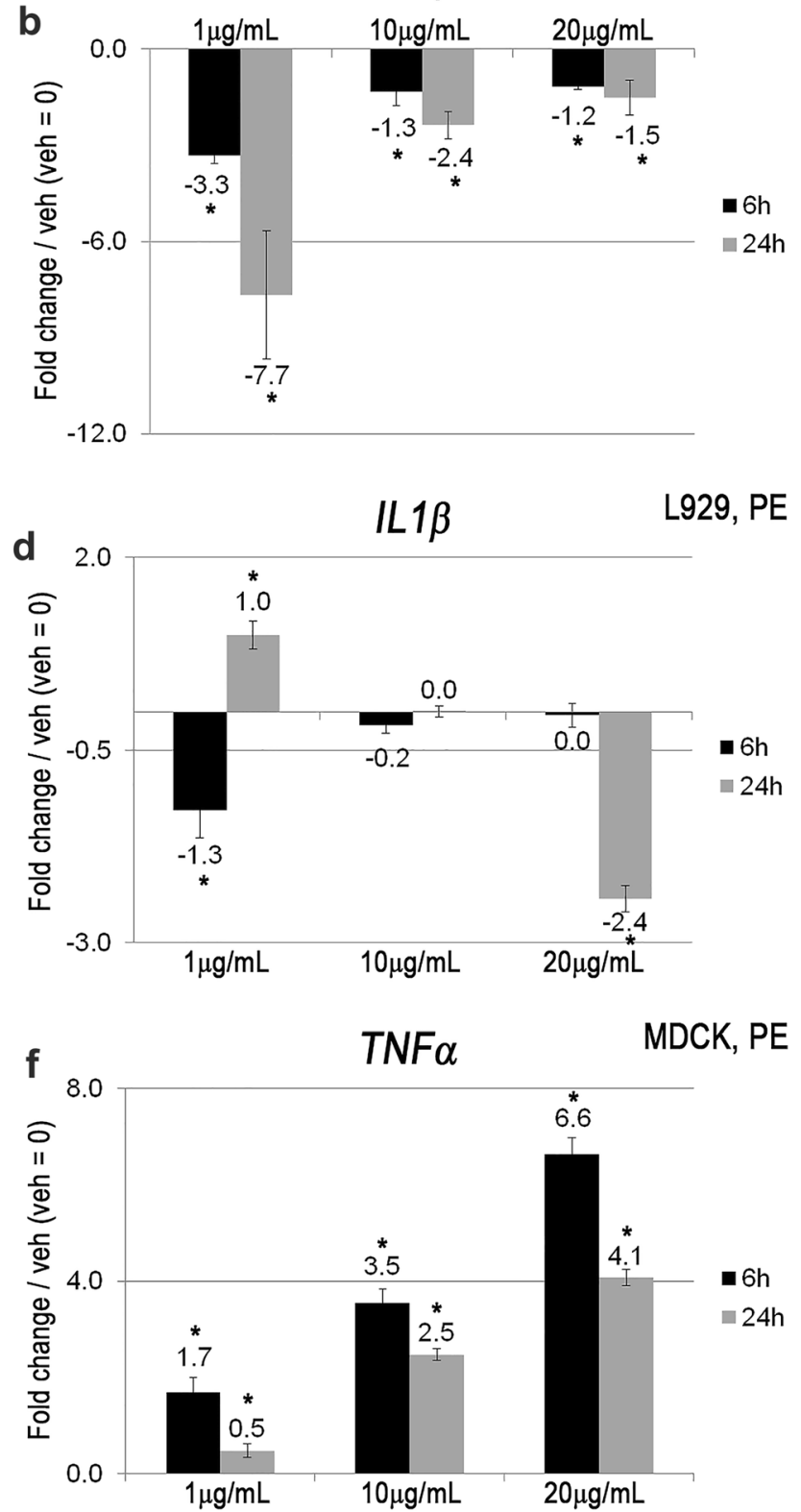

h

$T N F \alpha$

L929, PE

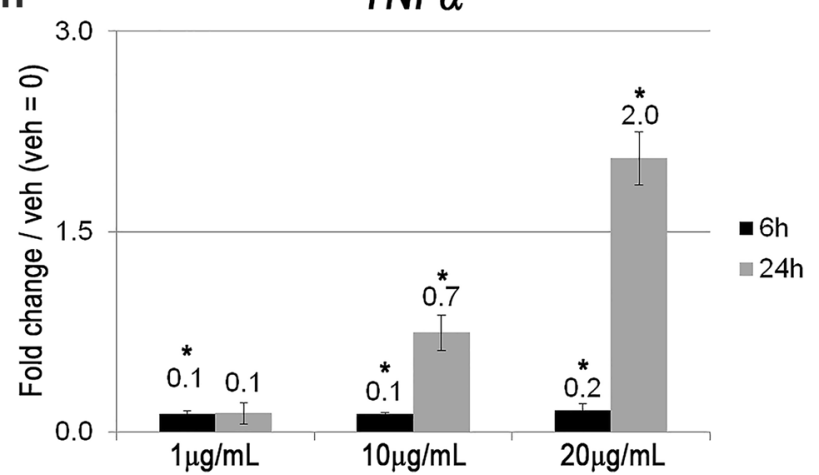


4Fig. 3 PS and PE microplastics decreased the transcriptional expression of $I L 1 \beta$ and increased the expression of $T N F \alpha$ inflammatory cytokines. MDCK (a and b, e and f) and L929 (c and d, g and h) cells were treated with PS or PE microplastics, or vehicle control for $6 \mathrm{~h}$ (black bars) or $24 \mathrm{~h}$ (gray bars) at $1 \mu \mathrm{g} / \mathrm{mL}, 10 \mu \mathrm{g} / \mathrm{mL}$, or $20 \mu \mathrm{g} /$ $\mathrm{mL}$, and whole cell lysates from each well were used to obtain the transcriptomes, which were converted to cDNA for qPCR analysis of ILI $\beta$ (a-d) and TNF $\alpha(\mathbf{e}-\mathbf{h})$ expression. The comparative $C_{\mathrm{T}}$ $\left(2^{-\Delta \Delta \mathrm{C}(\mathrm{T})}\right)$ method was used to determine fold changes relative to vehicle control (control $=0.0$ ). Each experiment was conducted in biological and technical duplicates. Error bars represent standard deviations. *Statistical significance of $P$ values $<0.05$, as determined by student's $t$ test for each condition relative to vehicle control

\section{Materials and Methods}

\section{Cell Culture}

Madin-Darby canine kidney (MDCK) epithelial and L929 mouse fibroblast cell lines were grown in complete EMEM (Lonza, Walkersville, MD): supplemented with $10 \%$ bovine calf serum (Avantor Seradigm, Radnor, PA) and $1 \mathrm{X}$ penicillin-streptomycin-amphotericin-B (Lonza). Cells were grown at $37{ }^{\circ} \mathrm{C}, 5 \% \mathrm{CO}_{2}$, and passaged $1: 4$ at $\sim 70 \%$ confluence using $0.25 \%$ trypsin (Cytiva Hyclone, Logan, UT). For experiments, cells were seeded in 6-well plates (Greiner Bio-One, Monroe, NC) at $1 \times 10^{4}$ cells/ well and grown $24 \mathrm{~h}$ to reach $\log$ growth phase before experimental treatments.

\section{Microplastics Exposure}

$1.0-4.0 \mu \mathrm{m}$ clear polyethylene microspheres and 9.5-11.5 $\mu \mathrm{m}$ polystyrene microspheres (Cospheric, Santa Barbara, CA) were resuspended in complete EMEM $+0.01 \%$ tween-20 at $1.0,10.0$, or $20.0 \mu \mathrm{g} / \mathrm{mL}$ concentrations, and complete EMEM $+0.01 \%$ tween- 20 without microplastics was used for vehicle control treatments. Concentrations of PS \& PE used to dose the cells were based on similar doses described in prior research articles (Hwang et al. 2020; Schirinzi et al. 2017). Cells at their logarithmic growth phase had their media removed, and $2 \mathrm{~mL}$ fresh media containing the various microplastic concentrations or vehicle control media was added for $6 \mathrm{~h}$ or $24 \mathrm{~h}$. Cell cultures and microplastic treatments were conducted separately and independently for each downstream assay. All treatment conditions and exposure times were conducted in biological duplicates, each of which was subsequently assayed in technical duplicates. For each downstream assay, the statistical significance was determined by comparing the four resulting data points for each experimental condition to the four respective vehicle control data points.

\section{Cell Viability Assay}

The effects of the microplastics on the viability of cell lines in culture were measured by counting the cells after $6 \mathrm{~h}$ or $24 \mathrm{~h}$ incubation. Cells treated with microplastics or vehicle controls were washed three times with PBS, detached using trypsin, and resuspended in $2 \mathrm{~mL}$ complete EMEM. Cells were counted using a hemacytometer (Sigma-Aldrich, Saint Louis, MO). Changes in cell viability with each microplastic concentration were compared for statistical significance relative to the vehicle control wells for each cell line, at each time point.

\section{MTT Assay}

To quantify changes in cellular metabolic activity, NAD $(\mathrm{P})$ $\mathrm{H}$-dependent enzymatic reduction of the tetrazolium dye 3-(4,5-dimethylthiazol-2-yl)-2,5-diphenyl tetrazolium bromide (MTT; MP Biomedicals, Solon, OH) to insoluble formazan precipitate was measured. Stock MTT solution was prepared in PBS at $5 \mathrm{mg} / \mathrm{mL}$. $200 \mu \mathrm{L}$ of stock MTT was added to the $2 \mathrm{~mL}$ complete cell media for a working concentration of $\sim 500 \mu \mathrm{g} / \mathrm{mL}$, and incubated during the final $4 \mathrm{~h}$ of each treatment condition. Cells were washed three times with PBS and $500 \mu \mathrm{L}$ dimethylsulfoxide (DMSO) was added to each well to dissolve the formazan, the plates were covered with aluminum foil, and gently agitated on a nutating shaker for $15 \mathrm{~min}$, and optical densities (OD) at $540 \mathrm{~nm}$ were measured on a Spectramax i3x spectrophotometer (Molecular Devices, Sunnyvale, CA). Background OD measurements were subtracted out using DMSO from atop cells without MTT incubation, and changes in metabolic activity were calculated relative to respective vehicle control-treated cells never exposed to microplastics. The MTT assay results for each condition were normalized to their respective number of cells per well.

\section{Quantitative Real-Time PCR Assays (qPCR)}

Analysis of relative change in gene transcripts was performed by qPCR assay. Phenol-chloroform RNA extraction was performed with Ribozol (Avantor VWR, Solon, $\mathrm{OH}$ ) using manufacturer's protocol. Under RNase-free conditions, at the conclusion of each experimental treatment, cells were washed three times with PBS (Lonza), $650 \mu \mathrm{L}$ of Ribozol was directly added to each well and triturated. Mixtures were collected in $1.5 \mathrm{~mL}$ tubes (USA Scientific, Ocala, FL) and $140 \mu \mathrm{L}$ of chloroform was added to each tube, mixed vigorously, and incubated $3 \mathrm{~min}$ at room temperature. Tubes were centrifuged at $12,000 \times g$ for $15 \mathrm{~min}$ at $4{ }^{\circ} \mathrm{C}$, the aqueous phase was transferred to new tubes, and RNA was precipitated by addition of $500 \mu \mathrm{L}$ isopropanol. Precipitated RNA was pelleted by $12,000 \times g$ centrifugation for $5 \mathrm{~min}$ 


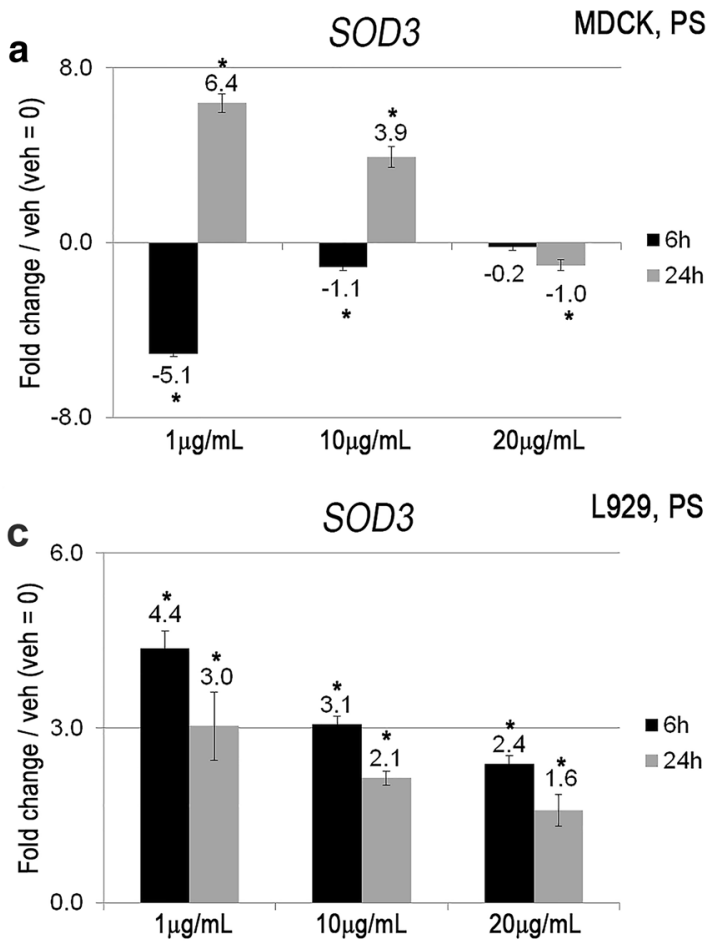

Fig. 4 PS and PE microplastics increased the transcriptional expression of the SOD3 antioxidant enzyme. MDCK $(\mathbf{a}, \mathbf{b})$ and L929 (c, d) cells were treated with PS (a, c) or PE $(\mathbf{b}, \mathbf{d})$ microplastics, or vehicle control for $6 \mathrm{~h}$ (black bars) or $24 \mathrm{~h}$ (gray bars) at $1 \mu \mathrm{g} / \mathrm{mL}, 10 \mu \mathrm{g} /$ $\mathrm{mL}$, or $20 \mu \mathrm{g} / \mathrm{mL}$, and whole cell lysates from each well were used to obtain the transcriptomes, which were converted to cDNA for qPCR

at $4{ }^{\circ} \mathrm{C}$, the pellet was washed three times with $75 \%$ ethanol, and resuspended in $50 \mu \mathrm{L}$ water. RNA concentrations were obtained using a Nanodrop One-C spectrophotometer (Thermo Scientific, Waltham, MA), and $4 \mu \mathrm{g}$ equalized volumes of RNA from each sample were used to create cDNA libraries using qScript Supermix (Quantabio, Beverly, MA). For the genes of interest, primer sequences were as follows $\left(5^{\prime}-3^{\prime}\right)$ : Sod3 Fwd, ATGGTGGCCTTCTTGTTCTGC; Sod3 Rev, GTGCTGTGGGTGCGGCACACC; $18 \mathrm{~S}$ Fwd, CGG ACAGGATTGACAGATTG; 18S Rev, CAAATCGCTCCA CCAACTAA; rat $I l l B$ Fwd, TGAAAGCTCTCCACCTCA ATGGAC; rat $I l l B$ Rev, TGCAGCCATCTTTAGGAAGAC ACG; rat TnfA Fwd, AGCACAGAAAGCATGATCCGAG; rat TnfA Rev, CCTGGTATGAAGTGGCAAATCG; canine $I l l B$ Fwd, TGCAAAACAGATGCGGATAA; canine $I l l B$ Rev, GTAACTTGCAGTCCACCGATT; canine TnfA Fwd, CGTCCATTCTTGCCCAAAC; canine TnfA Rev, AGCCCT GAGCCCTTAATTC. qPCR was performed on a StepOne Plus RT-PCR system (Applied Biosystems, Foster City, CA), using Power SYBR-Green Master Mix (Applied Biosystems), and all biological replicates were run in technical duplicates using $10 \mathrm{ng}$ of template, $15 \mu \mathrm{L}$ reaction volume. The optimized annealing temperature for all primer pairs
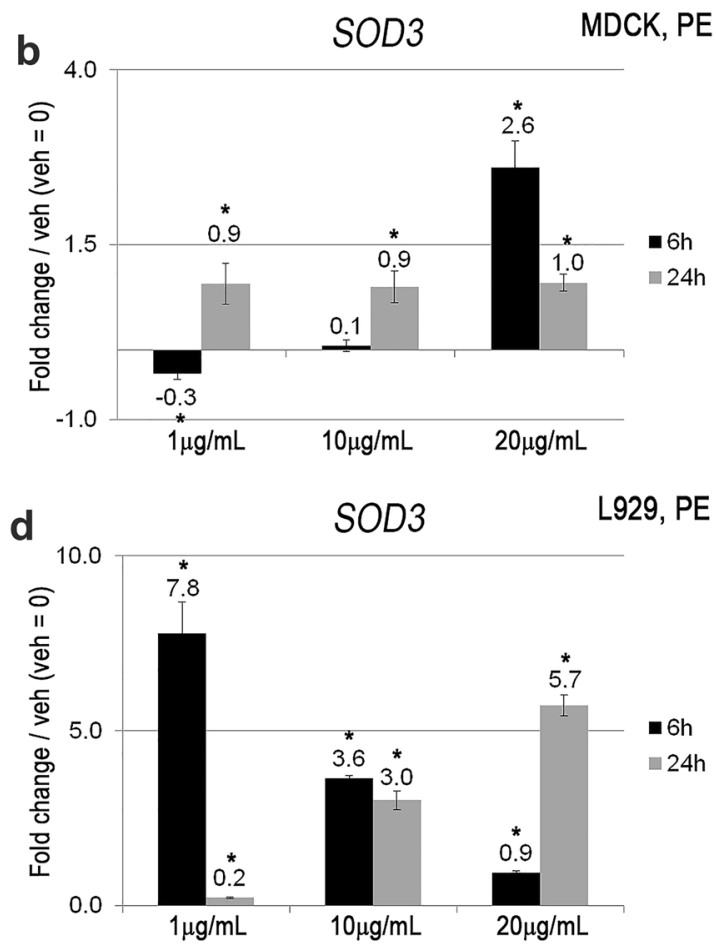

analysis of SOD3 expression. The comparative $C_{\mathrm{T}}\left(2^{-\Delta \Delta \mathrm{C}(\mathrm{T})}\right)$ method was used to determine fold changes relative to vehicle control (control $=0.0$ ). Each experiment was conducted in biological and technical duplicates. Error bars represent standard deviations. *Statistical significance of $P$ values $<0.05$, as determined by student's $t$ test for each condition relative to vehicle control

was $48.0^{\circ} \mathrm{C}$, and the thermal cycling conditions were: stage $1,95.0^{\circ} \mathrm{C}$ for $5 \mathrm{~min}$; stage 2 ( 40 cycles), step $1,95.0^{\circ} \mathrm{C}$ for $30 \mathrm{~s}$; step $2,48.0^{\circ} \mathrm{C}$ for $30 \mathrm{~s}$; step $3,74.0^{\circ} \mathrm{C}$ for $45 \mathrm{~s}$; stage 3 , infinite hold at $4.0^{\circ} \mathrm{C}$. The comparative $C_{\mathrm{T}}\left(2^{-\Delta \Delta \mathrm{C}(\mathrm{T})}\right)$ method was used to calculate transcript fold changes relative to experimental controls, and changes in expression of genes of interest were normalized to $18 \mathrm{~S}$ housekeeping genes. $18 \mathrm{~S}$ expression remained relatively stable in both vehicle control and microplastics-treated experimental conditions, as determined by $C(t)$ values (data not shown).

\section{Statistical Analyses}

Student's two-tailed $t$-tests were used for pair-wise analyses against controls, and comparisons were considered statistically significant at or below $P<0.05$. Standard deviations were derived from the four data points obtained from each set of biological and technical duplicates.

Acknowledgements The authors would like to thank Dr. Yung-Fu Chang of Cornell University for generously providing the MDCK cells. We also thank Integrated DNA Technologies (IDT, Coralville, IA) for providing the qPCR primers free of charge for use in the qPCR assays performed in this study. We would also like to thank Cospheric 
(Santa Barbara, CA), VWR International (Radnor, PA), and Bio-Rad Laboratories (Hercules, CA) for providing student discounts for many of the consumable products used to conduct the experiments in this study. We also thank Ms. Amy Devries of Cape Elizabeth High School, Maine, for her guidance and mentorship. We acknowledge and thank Drs. Meghan May, Deena Small, and Ling Cao of the University of New England for providing the use of their laboratory space to conduct this work. We thank Ms. Rema Weston for her help in procuring the additional materials used to perform the experiments.

Author Contributions Conceptualization: [SP]; Data curation: [SP, BR]; Formal analysis: [SP, BR]; Investigation: [SP, BR]; Methodology: [BR]; Project administration: [BR, CMS]; Resources: [SP, BR, CMS]; Software: [SP, BR]; Supervision: [BR]; Validation: [BR]; Visualization: [BR]; Writing (original draft): [SP, BR]; Writing (review \& editing): [SP, BR, and CMS].

Funding No funds or grants were received from any organization for the submitted work.

Data Availability The data, codes, and materials generated and analyzed in this published article are available from the corresponding author upon reasonable request.

\section{Declarations}

Conflict of interest All authors certify that they have no affiliation with or involvement in any organization or entity with any financial or nonfinancial interests in the subject matter or materials discussed in this manuscript.

Ethical Approval Not applicable.

Consent to Participate Not applicable.

Consent for Publication Not applicable.

\section{References}

Abidli S, Pinheiro M, Lahbib Y, Neuparth T, Santos MM, Trigui El Menif N (2021) Effects of environmentally relevant levels of polyethylene microplastic on Mytilus galloprovincialis (Mollusca: Bivalvia): filtration rate and oxidative stress. Environ Sci Pollut Res Int 28:26643-26652

Akhbarizadeh R, Moore F, Keshavarzi B (2018) Investigating a probable relationship between microplastics and potentially toxic elements in fish muscles from northeast of Persian Gulf. Environ Pollut 232:154-163

Al-Sid-Cheikh M, Rowland SJ, Stevenson K, Rouleau C, Henry TB, Thompson RC (2018) Uptake, whole-body distribution, and depuration of nanoplastics by the scallop Pecten maximus at environmentally realistic concentrations. Environ Sci Technol 52(24):14480-14486

Alexy P, Anklam E, Emans T, Furfari A, Galgani F, Hanke G, Koelmans A, Pant R, Saveyn H, Sokull Kluettgen B (2020) Managing the analytical challenges related to micro- and nanoplastics in the environment and food: filling the knowledge gaps. Food Addit Contam Part A Chem Anal Control Expo Risk Assess 37(1):1-10

Alimba CG, Faggio C (2019) Microplastics in the marine environment: current trends in environmental pollution and mechanisms of toxicological profile. Environ Toxicol Pharmacol 68:61-74
An R, Wang X, Yang L, Zhang J, Wang N, Xu F, Hou Y, Zhang H, Zhang L (2021) Polystyrene microplastics cause granulosa cells apoptosis and fibrosis in ovary through oxidative stress in rats. Toxicology 449:152665

Belzagui F, Buscio V, Gutierrez-Bouzan C, Vilaseca M (2021) Cigarette butts as a microfiber source with a microplastic level of concern. Sci Total Environ 762:144165

Blackburn K, Green D (2021) The potential effects of microplastics on human health: What is known and what is unknown. Ambio. https://doi.org/10.1007/s13280-021-01589-9

Brachner A, Fragouli D, Duarte IF, Farias PMA, Dembski S, Ghosh M, Barisic I, Zdzieblo D, Vanoirbeek J, Schwabl P, Neuhaus W (2020) Assessment of human health risks posed by nano-and microplastics is currently not feasible. Int J Environ Res Public Health 17(23):8832

Browne MA, Dissanayake A, Galloway TS, Lowe DM, Thompson RC (2008) Ingested microscopic plastic translocates to the circulatory system of the mussel, Mytilus edulis (L). Environ Sci Technol 42(13):5026-5031

Chen H, Hua X, Li H, Wang C, Dang Y, Ding P, Yu Y (2021) Transgenerational neurotoxicity of polystyrene microplastics induced by oxidative stress in Caenorhabditis elegans. Chemosphere 272:129642

Choi HS, Ashitate Y, Lee JH, Kim SH, Matsui A, Insin N, Bawendi MG, Semmler-Behnke M, Frangioni JV, Tsuda A (2010) Rapid translocation of nanoparticles from the lung airspaces to the body. Nat Biotechnol 28(12):1300-1303

Choi D, Hwang J, Bang J, Han S, Kim T, Oh Y, Hwang Y, Choi J, Hong $\mathbf{J}$ (2021a) In vitro toxicity from a physical perspective of polyethylene microplastics based on statistical curvature change analysis. Sci Total Environ 752:142242

Choi YJ, Park JW, Kim JE, Lee SJ, Gong JE, Jung YS, Seo S, Hwang DY (2021b) Novel characterization of constipation phenotypes in ICR mice orally administrated with polystyrene microplastics. Int J Mol Sci 22(11):5845

Cortés C, Domenech J, Salazar M, Pastor S, Marcos R, Hernández A (2020) Nanoplastics as a potential environmental health factor: effects of polystyrene nanoparticles on human intestinal epithelial Caco-2 cells. Environ Sci Nano 7(1):272-285

Cox KD, Covernton GA, Davies HL, Dower JF, Juanes F, Dudas SE (2019) Human consumption of microplastics. Environ Sci Technol 53(12):7068-7074

Cox KD, Covernton GA, Davies HL, Dower JF, Juanes F, Dudas SE (2020) Correction to human consumption of microplastics. Environ Sci Technol 54(17): 10974

da Costa Araujo AP, Malafaia G (2021) Microplastic ingestion induces behavioral disorders in mice: a preliminary study on the trophic transfer effects via tadpoles and fish. J Hazard Mater 401:123263

Della Torre C, Bergami E, Salvati A, Faleri C, Cirino P, Dawson KA, Corsi I (2014) Accumulation and embryotoxicity of polystyrene nanoparticles at early stage of development of sea urchin embryos Paracentrotus lividus. Environ Sci Technol 48(20):12302-12311

Deng Y, Zhang Y, Lemos B, Ren H (2017) Tissue accumulation of microplastics in mice and biomarker responses suggest widespread health risks of exposure. Sci Rep 7:46687

Ding J, Huang Y, Liu S, Zhang S, Zou H, Wang Z, Zhu W, Geng J (2020) Toxicological effects of nano- and micro-polystyrene plastics on red tilapia: are larger plastic particles more harmless? J Hazard Mater 396:122693

Estrela FN, Guimaraes ATB, Araujo A, Silva FG, Luz TMD, Silva AM, Pereira PS, Malafaia G (2020) Toxicity of polystyrene nanoplastics and zinc oxide to mice. Chemosphere 271:129476

Foley CJ, Feiner ZS, Malinich TD, Hook TO (2018) A meta-analysis of the effects of exposure to microplastics on fish and aquatic invertebrates. Sci Total Environ 631-632:550-559 
Gonzalez-Acedo A, Garcia-Recio E, Illescas-Montes R, Ramos-Torrecillas J, Melguizo-Rodriguez L, Costela-Ruiz VJ (2021) Evidence from in vitro and in vivo studies on the potential health repercussions of micro- and nanoplastics. Chemosphere 280:130826

Hicks DG, Judkins AR, Sickel JZ, Rosier RN, Puzas JE, O'Keefe RJ (1996) Granular histiocytosis of pelvic lymph nodes following total hip arthroplasty. The presence of wear debris, cytokine production, and immunologically activated macrophages. J Bone Jt Surg Am 78(4):482-496

Hou J, Lei Z, Cui L, Hou Y, Yang L, An R, Wang Q, Li S, Zhang H, Zhang L (2021) Polystyrene microplastics lead to pyroptosis and apoptosis of ovarian granulosa cells via NLRP3/Caspase-1 signaling pathway in rats. Ecotoxicol Environ Saf 212:112012

Huffer T, Weniger AK, Hofmann T (2018) Data on sorption of organic compounds by aged polystyrene microplastic particles. Data $\mathrm{Br}$ 18:474-479

Hussain N, Jaitley V, Florence AT (2001) Recent advances in the understanding of uptake of microparticulates across the gastrointestinal lymphatics. Adv Drug Deliv Rev 50(1-2):107-142

Hwang J, Choi D, Han S, Jung SY, Choi J, Hong J (2020) Potential toxicity of polystyrene microplastic particles. Sci Rep 10(1):7391

Ibrahim YS, Tuan Anuar S, Azmi AA, Wan Mohd Khalik WMA, Lehata S, Hamzah SR, Ismail D, Ma ZF, Dzulkarnaen A, Zakaria Z, Mustaffa N, Tuan Sharif SE, Lee YY (2021) Detection of microplastics in human colectomy specimens. JGH Open 5(1):116-121

Ijaz MU, Shahzadi S, Samad A, Ehsan N, Ahmed H, Tahir A, Rehman H, Anwar H (2021) Dose-dependent effect of polystyrene microplastics on the testicular tissues of the male Sprague Dawley rats. Dose Response 19(2):15593258211019882

Jin Y, Lu L, Tu W, Luo T, Fu Z (2019) Impacts of polystyrene microplastic on the gut barrier, microbiota and metabolism of mice. Sci Total Environ 649:308-317

Jin H, Ma T, Sha X, Liu Z, Zhou Y, Meng X, Chen Y, Han X, Ding J (2021) Polystyrene microplastics induced male reproductive toxicity in mice. J Hazard Mater 401:123430

Karkkainen N, Sillanpaa M (2020) Quantification of different microplastic fibres discharged from textiles in machine wash and tumble drying. Environ Sci Pollut Res Int 28:16253-16263

Koski M, Sondergaard J, Christensen AM, Nielsen TG (2021) Effect of environmentally relevant concentrations of potentially toxic microplastic on coastal copepods. Aquat Toxicol 230:105713

Kumar M, Chen H, Sarsaiya S, Qin S, Liu H, Awasthi MK, Kumar S, Singh L, Zhang Z, Bolan NS, Pandey A, Varjani S, Taherzadeh MJ (2020) Current research trends on micro- and nano-plastics as an emerging threat to global environment: a review. J Hazard Mater 409:124967

Lee HS, Amarakoon D, Wei CI, Choi KY, Smolensky D, Lee SH (2021) Adverse effect of polystyrene microplastics (PS-MPs) on tube formation and viability of human umbilical vein endothelial cells. Food Chem Toxicol 154:112356

Li D, Shi Y, Yang L, Xiao L, Kehoe DK, Gun'ko YK, Boland JJ, Wang JJ (2020a) Microplastic release from the degradation of polypropylene feeding bottles during infant formula preparation. Nat Food 1(11):746-754

Li G, Zhang H, Ma H, Qu S, Xing Q, Wang G (2020b) MiR-221-5p is involved in the regulation of inflammatory responses in acute gouty arthritis by targeting IL-1beta. Int J Rheum Dis 24:335-340

Li L, Zhao X, Li Z, Song K (2020c) COVID-19: performance study of microplastic inhalation risk posed by wearing masks. J Hazard Mater 411:124955

Li Z, Zhu S, Liu Q, Wei J, Jin Y, Wang X, Zhang L (2020d) Polystyrene microplastics cause cardiac fibrosis by activating Wnt/ beta-catenin signaling pathway and promoting cardiomyocyte apoptosis in rats. Environ Pollut 265(Pt A):115025
Liang B, Zhong Y, Huang Y, Lin X, Liu J, Lin L, Hu M, Jiang J, Dai M, Wang B, Zhang B, Meng H, Lelaka JJJ, Sui H, Yang $X$, Huang $Z$ (2021) Underestimated health risks: polystyrene micro- and nanoplastics jointly induce intestinal barrier dysfunction by ROS-mediated epithelial cell apoptosis. Part Fibre Toxicol 18(1):20

Liu Q, Chen C, Li M, Ke J, Huang Y, Bian Y, Guo S, Wu Y, Han Y, Liu M (2020) Neurodevelopmental toxicity of polystyrene nanoplastics in Caenorhabditis elegans and the regulating effect of presenilin. ACS Omega 5(51):33170-33177

Lu L, Wan Z, Luo T, Fu Z, Jin Y (2018) Polystyrene microplastics induce gut microbiota dysbiosis and hepatic lipid metabolism disorder in mice. Sci Total Environ 631-632:449-458

Mahadevan G, Valiyaveettil S (2021) Understanding the interactions of poly(methyl methacrylate) and poly(vinyl chloride) nanoparticles with BHK-21 cell line. Sci Rep 11(1):2089

Markel DC, Zhang R, Shi T, Hawkins M, Ren W (2009) Inhibitory effects of erythromycin on wear debris-induced VEGF/Flt-1 gene production and osteolysis. Inflamm Res 58(7):413-421

Mengistu D, Heistad A, Coutris C (2021) Tire wear particles concentrations in gully pot sediments. Sci Total Environ 769:144785

Nobre CR, Santana MFM, Maluf A, Cortez FS, Cesar A, Pereira CDS, Turra A (2015) Assessment of microplastic toxicity to embryonic development of the sea urchin Lytechinus variegatus (Echinodermata: Echinoidea). Mar Pollut Bull 92(1-2):99-104

Oeckinghaus A, Ghosh S (2009) The NF-kappaB family of transcription factors and its regulation. Cold Spring Harb Perspect Biol 1(4):a000034

Pearl JI, Ma T, Irani AR, Huang Z, Robinson WH, Smith RL, Goodman SB (2011) Role of the Toll-like receptor pathway in the recognition of orthopedic implant wear-debris particles. Biomaterials 32(24):5535-5542

Pivokonsky M, Cermakova L, Novotna K, Peer P, Cajthaml T, Janda $\mathrm{V}$ (2018) Occurrence of microplastics in raw and treated drinking water. Sci Total Environ 643:1644-1651

Prata JC (2018) Airborne microplastics: consequences to human health? Environ Pollut 234:115-126

Prata JC, da Costa JP, Lopes I, Duarte AC, Rocha-Santos T (2020) Environmental exposure to microplastics: an overview on possible human health effects. Sci Total Environ 702:134455

Ramsperger A, Narayana VKB, Gross W, Mohanraj J, Thelakkat M, Greiner A, Schmalz H, Kress H, Laforsch C (2020) Environmental exposure enhances the internalization of microplastic particles into cells. Sci Adv 6(50):eabd1211

Razeghi N, Hamidian AH, Wu C, Zhang Y, Yang M (2021) Scientific studies on microplastics pollution in Iran: an in-depth review of the published articles. Mar Pollut Bull 162:111901

Ribeiro F, Okoffo ED, O'Brien JW, Fraissinet-Tachet S, O'Brien S, Gallen M, Samanipour S, Kaserzon S, Mueller JF, Galloway T, Thomas KV (2020) Quantitative analysis of selected plastics in high-commercial-value Australian seafood by pyrolysis gas chromatography mass spectrometry. Environ Sci Technol 54(15):9408-9417

Roy A, Srivastava M, Saqib U, Liu D, Faisal SM, Sugathan S, Bishnoi S, Baig MS (2016) Potential therapeutic targets for inflammation in toll-like receptor 4 (TLR4)-mediated signaling pathways. Int Immunopharmacol 40:79-89

Schirinzi GF, Perez-Pomeda I, Sanchis J, Rossini C, Farre M, Barcelo D (2017) Cytotoxic effects of commonly used nanomaterials and microplastics on cerebral and epithelial human cells. Environ Res 159:579-587

Schwabl P, Koppel S, Konigshofer P, Bucsics T, Trauner M, Reiberger T, Liebmann B (2019) Detection of various microplastics in human stool: a prospective case series. Ann Intern Med 171(7):453-457 
Scopetani C, Cincinelli A, Martellini T, Lombardini E, Ciofini A, Fortunati A, Pasquali V, Ciattini S, Ugolini A (2018) Ingested microplastic as a two-way transporter for PBDEs in Talitrus saltator. Environ Res 167:411-417

Shen XF, Cheng Y, Dong QR, Zheng MQ (2020) MicroRNA-675-3p regulates IL-1beta-stimulated human chondrocyte apoptosis and cartilage degradation by targeting GNG5. Biochem Biophys Res Commun 527(2):458-465

Su Y, Zhang Z, Zhu J, Shi J, Wei H, Xie B, Shi H (2021) Microplastics act as vectors for antibiotic resistance genes in landfill leachate: the enhanced roles of the long-term aging process. Environ Pollut 270:116278

Torres FG, Dioses-Salinas DC, Pizarro-Ortega CI, De-la-Torre GE (2021) Sorption of chemical contaminants on degradable and nondegradable microplastics: recent progress and research trends. Sci Total Environ 757:143875

Urban RM, Jacobs JJ, Tomlinson MJ, Gavrilovic J, Black J, Peoc'h M (2000) Dissemination of wear particles to the liver, spleen, and abdominal lymph nodes of patients with hip or knee replacement. J Bone Jt Surg Am 82(4):457-476

Van Tienhoven EA, Korbee D, Schipper L, Verharen HW, De Jong WH (2006) In vitro and in vivo (cyto)toxicity assays using PVC and LDPE as model materials. J Biomed Mater Res A 78(1):175-182

Volkheimer G (1975) Hematogenous dissemination of ingested polyvinyl chloride particles. Ann NY Acad Sci 246:164-171

Walmsley S, Harris A, Thompson AAR, Whyte MKB (2014) HIFmediated innate immune responses: cell signaling and therapeutic implications. Hypoxia 2:47

Wang Z, Gao J, Dai H, Zhao Y, Li D, Duan W, Guo Y (2020) Microplastics affect the ammonia oxidation performance of aerobic granular sludge and enrich the intracellular and extracellular antibiotic resistance genes. J Hazard Mater 409:124981

Wei J, Wang X, Liu Q, Zhou N, Zhu S, Li Z, Li X, Yao J, Zhang L (2021) The impact of polystyrene microplastics on cardiomyocytes pyroptosis through NLRP3/Caspase-1 signaling pathway and oxidative stress in Wistar rats. Environ Toxicol 36:935-944

Wen H, Ting JP (2013) Agitation by suffocation: how hypoxia activates innate immunity via the Warburg effect. Cell Metab 17(6):814-815

Wen B, Zhang N, Jin SR, Chen ZZ, Gao JZ, Liu Y, Liu HP, Xu Z (2018) Microplastics have a more profound impact than elevated temperatures on the predatory performance, digestion and energy metabolism of an Amazonian cichlid. Aquat Toxicol 195:67-76

Wu S, Wu M, Tian D, Qiu L, Li T (2020) Effects of polystyrene microbeads on cytotoxicity and transcriptomic profiles in human Caco-2 cells. Environ Toxicol 35(4):495-506

Zarus GM, Muianga C, Hunter CM, Pappas RS (2021) A review of data for quantifying human exposures to micro and nanoplastics and potential health risks. Sci Total Environ 756:144010

Zhang H, Ricciardi BF, Yang X, Shi Y, Camacho NP, Bostrom MG (2008) Polymethylmethacrylate particles stimulate bone resorption of mature osteoclasts in vitro. Acta Orthop 79(2):281-288

Zhang N, Li YB, He HR, Zhang JF, Ma GS (2020a) You are what you eat: microplastics in the feces of young men living in Beijing. Sci Total Environ 767:144345

Zhang Q, Xu EG, Li J, Chen Q, Ma L, Zeng EY, Shi H (2020b) A review of microplastics in table salt, drinking water, and air: direct human exposure. Environ Sci Technol 54(7):3740-3751

Zhao Z, Du S, Shen S, Wang L (2020) microRNA-132 inhibits cardiomyocyte apoptosis and myocardial remodeling in myocardial infarction by targeting IL-1beta. J Cell Physiol 235(3):2710-2721

Publisher's Note Springer Nature remains neutral with regard to jurisdictional claims in published maps and institutional affiliations. 